\title{
Ductal Breast Carcinoma In Situ, Solid Type
}

National Cancer Institute

\section{Source}

National Cancer Institute. Ductal Breast Carcinoma In Situ, Solid Type. NCI Thesaurus.

Code C66933.

A ductal carcinoma in situ of the breast in which the tumor cells fill the ductal spaces as solid sheets. 